\title{
EFFECT OF SELECTED YOGA TECHNIQUES ALONG WITH ASHWAGANDHA AND VACHA IN DEPRESSION IN THE AGE GROUP 65-75 YEARS
}

\author{
SOUMYA MELEPPURAKKAL ${ }^{1 *}$, SUNITHA V K ${ }^{2}$, JAYAN D ${ }^{2}$ \\ ${ }^{1}$ Consultant Physician Swastha Ayurveda Specialty Clinic Athani, Ernakulam, Kerala, India. ${ }^{2}$ Department of Swasthavritta, Government \\ Ayurveda College, Thiruvananthapuram, Kerala, India. Email: dr.soumya86@gmail.com
}

Received: 31 May 2021, Revised and Accepted: 25 September 2021

\section{ABSTRACT}

Objective: The study was done to compare the effect of selected yoga techniques, drugs, and combined therapy in depression in geriatrics.

Methods: 75 patients between 65 and 75 years of age with depression were included in the study which was assessed by HAM D Score. The study population was randomly allocated to one control group and two study groups. The control group was given Aswangandha and Vacha churna with warm water as anupana after food, selected yoga techniques in the first study group, and combined yoga and the drug were given to the second study group. Outcome variables were assessed for the groups after the $30^{\text {th }}$ day and follow-up after 45 days.

Results: The results obtained in the study were analyzed using the ANOVA test. Yoga along with drug experienced a comparatively greater reduction in HAM-D score after treatment and follow-up $(\mathrm{p}<0.05)$ than other groups.

Conclusion: Holistic approach can bring a better and static result than applying the treatment modalities alone.

Keywords: Depression, Geriatric, Ham D, Yoga, Ashwagandha, Vacha.

(C) 2021 The Authors. Published by Innovare Academic Sciences Pvt Ltd. This is an open access article under the CC BY license (http://creativecommons.org/ licenses/by/4.0/) DOI: http://dx.doi.org/10.22159/ajpcr.2021v14i11.42259. Journal homepage: https://innovareacademics.in/journals/index.php/ajpcr

\section{INTRODUCTION}

Depression is among the leading causes of Disability Adjusted Life Years (DALY) in the world and a serious public health problem among older adults. It is projected to be among the top three causes of DALY's lost by the year 2030 [1]. There is an alarming rise in the population of elderly in Kerala. It was 2.2 million in 1986 and rose to 4.6 million in 2011. It is expected to reach 8.3 million in 2026 [2]. Geriatric depression is a mental and emotional disorder affecting older adults. Feeling of sadness and occasional "blue" moods are normal. The elderly are more likely to suffer from subsyndromal depression. This type of depression does not meet the full criteria for major depression [1]

Yoga and Ayurveda are two great holistic sciences that aim to harmonize the body, mind, and soul. Thus Yoga is a union of the individual soul or consciousness with Cosmic, Divine or Supreme Soul or Consciousness or a total integration of the physical, mental, intellectual, and spiritual aspects of the human personality [3]. While defining health Ayurveda emphasizes the importance of the maintenance of clarity of mind and sense organs. Thus, this holistic approach can be applied for maintaining peace and tranquility of mind to obtain optimum results. The development of the mind in man-made him superior to all other living beings. So maintenance of mental health is very important. Ayurveda deals with four aspects of lifestyle which can ensure good health, dharma (virtuous acts), artha (acquirement of wealth), kama (gratification of desire), and moksha (final emancipation) [4].

In old age, progressive generalized impairment of functions occurs which results in loss of adaptive responses to depression, feeling of tiredness, and poor concentration. New surveys show a rise of old age homes in the private and government sector.

Ayurvedic formulations are effective in depression management. Aswagandha and Vacha are the drugs taken in the study.

Depriving mental health of elderly people due to these adverse circumstances and shattering family relationships can be strengthened through the holistic approaches of Yoga and Ayurveda. There is ample scope for research into the degenerative and other diseases such as depression in old age, their treatment, finally into preventive geriatrics, and the epidemiology of conditions affecting the aged. Individual, integrated, and static effects of Yoga and Ayurvedic formulation in geriatric depression can be assessed from the study.

\section{METHODS}

We conducted this study as a randomized control trial in the department of Swasthavritta at OPD of Swasthavritta, Panchakarma Hospital, Poojappura, Govt. Ayurveda College, Thiruvananthapuram. 75 patients in the age group of 65-75 years including both sexes diagnosed as mild and moderate depression as defined by ICD 10 criteria were selected as the study population.

\section{Inclusion criteria}

Patients of both sexes aged between 65 and 75 years diagnosed with mild and moderate depression based on ICD 10 TR (international classification of diseases tenth revision) criteria.

Patients with depression irrespective of medication history for the same.
Exclusion criteria
- Lack of consent
- Severe depression based on ICD 10 TR criteria
- Individuals with dementia, stroke.
- Individuals with significant psychiatric impairment
- Patients did not fit for doing yoga.

The study was conducted for 2 years. Study participants were randomly allocated to one control group and two study groups as per the block randomization method. The control group received the drug proven as per previously published literature [5]. 4 g churna consisted of $3.75 \mathrm{gm}$ Aswagandha and $250 \mathrm{mg}$ of Vacha given twice a day with water as anupana to the control group. The first study group (SG1) was 
given selected yoga techniques which were included after a pilot study. The second study group (SG2) was given a selected yoga technique along with churna as in the control group. The duration of the trial was 30 days which was followed up after 45 days.

\section{Preparation and ingredients of churna}

Ashwagandha - Withania somnifera(Linn) Dunal

Vacha - Acorus calamus Linn.

$25 \mathrm{~kg}$ of ashwagandha was taken in a vessel. Milk was poured till it dips the ashwagandha roots fully. The vessel was kept on fire. Aswagandha roots were boiled until the milk get reduced completely [6]. The same procedure was repeated 3 times. After that ashwagandha roots were taken and dried in the sunlight. After proper drying ashwagandha roots were powdered in a very fine manner in a grinding mill and kept airtight in non-reactive containers.

$1.5 \mathrm{~kg}$ of Vacha rhizomes were taken and dried properly in sunlight. After proper drying Vacha rhizomes were powdered in a very fine manner in a grinding mill and kept airtight in non-reactive containers.

The selected yoga techniques were practiced in the patients of the first study group (yoga). It includes an initial prayer followed by sukshmavyayama [7] (loosening exercises). Next in sitting posture Vakrasana [8] was done followed by Pavanamuktasana [9] in the supine position and Bujangasana [10] and Makarasana [11] in the prone position. In the next stage, Pranayamas [12] such as Suryabhedi, Chandrabhedi, Naadishudhi pranayama, and Bhramari Pranayama were given. Finally, Savasana followed by $20 \mathrm{~min}$ of Deep relaxation technique and Yoga Nidra [13] were given. A combination of selected yoga and churna was given in the second study group. The objective of the study was to assess the effect of selected Yoga techniques along with ashwagandha and Vacha in depression in the age group 65-75years. The three groups were observed before treatment, after treatment, and after follow-up. Changes in the variables were compared between the groups and are statistically analyzed. The drug has been selected from an already proven study. Consent from the patients and the Institutional Ethical Committee was also obtained before the study.

\section{Study design}

Randomized Controlled Trial.

\section{Sample size}

Sample size (n) is calculated by the formula given by

Where $\mathrm{Z} \alpha=1.96$ and $\mathrm{Z} \beta=.84$

"SD" is Standard Deviation

"d" is Mean difference

"SD" and " $\mathrm{d}$ " value is calculated from the previous study on Depression with the Hamilton Rating Scale. The value of "SD" was 4.255 and "d" value was 3.5 . With these values " $n$ " is calculated to be 23 . So we will upsize the sample size to 25 to cover up the dropouts if at all there will be.

\section{Sampling technique}

Balanced randomization of successive blocks

75 patients of both sexes between 65 and 75 years of age with depression were randomly allocated into three groups by block randomization done with "WINPEPI" software [14].

\section{Statistical analysis}

Quantitative variables were expressed as mean and standard deviation. Qualitative variables were expressed as a proportion. Change in quantitative variables in successive observation and the comparison of changes between the three groups was analyzed by repeated measure ANOVA. Comparison of qualitative variables between three groups was analyzed by Chi-square test. Paired t-test was done for analyzing the difference in successive observations, (BT-AT), (AT-AF), and (BT-AF) statistically. $\mathrm{p}<0.05$ was considered statistically significant. Data analysis was performed using SPSS Ver. 22.0.

\section{Ethical consideration}

The selected yoga techniques and the Ayurvedic formulation have no side effects and complications. The drug has been selected from an already proven study. Consent from the patients and the Institutional Ethical Committee was also obtained before the study.

\section{RESULTS}

There were 34 males and 41 females as participants.

Data related to Hamilton's rating scale and response to treatment Between the group analysis using one way-ANOVA

The control group and both study groups showed a significant reduction in the total score of the Hamilton Rating Scale for Depression after treatment and after follow-up period. Results were more significant in the second study group than in other groups (Table 1).

The average score of Insomnia late, Agitation, Anxiety somatic, Genital score, Hypochondriasis showed $\mathrm{p}>0.05$.

The depression level of the patients after treatment among the three groups was comparable ( $p>0.05$ ), that is there was no difference among the groups. All the groups showed improvement almost similar change. There was the difference in improvement among the groups after follow-up in levels of depression $(p<0.05)$. The second study group showed a significant reduction than other groups (Table 2).

\section{Data related to total score}

The control group and both the study groups showed significant reduction in the total score of the Hamilton Rating Scale for Depression after treatment and after follow-up. Results were more significant in the yoga and drug group after treatment and after follow-up (Table 3).

\section{Repeated Measure ANOVA}

Average HAM-D score, before treatment among the control group, first study group, and second study group was $14.12 \pm 2.93,12.96 \pm 3.17$, and $14.36 \pm 2.64$, respectively (Table 4).

The observed difference in average HAM-D score before treatment was not statistically significant $(\mathrm{p}>0.05)$.

Table 1: HAM D variable and significant response with different arms

\begin{tabular}{|c|c|c|c|}
\hline $\begin{array}{l}\text { Ham D } \\
\text { variables }\end{array}$ & Treatment level & Group & $p$ value \\
\hline Depressed mood & After follow up & Drug and Yoga (SG2) & $<0.05$ \\
\hline Suicide & After follow up & Drug and Yoga (SG2) & $<0.05$ \\
\hline Loss of weight & After follow up & Drug and Yoga (SG2) & $<0.05$ \\
\hline $\begin{array}{l}\text { Work and } \\
\text { activities }\end{array}$ & After follow up & Drug and Yoga (SG2) & $<0.05$ \\
\hline Guilt & After treatment & $\begin{array}{l}\text { Control group } \\
\text { (Drug) }\end{array}$ & $<0.05$ \\
\hline Insomnia middle & After treatment & Yoga (SG1) & $<0.05$ \\
\hline Anxiety psychic & After treatment & Drug and Yoga (SG2) & $<0.05$ \\
\hline Somatic general & $\begin{array}{l}\text { After treatment } \\
\text { and after follow } \\
\text { up }\end{array}$ & Drug and Yoga (SG2) & $<0.05$ \\
\hline
\end{tabular}

Table 2: HAM-D score related to levels of depression

\begin{tabular}{lc}
\hline Before treatment & Group with $\%$ \\
Mild depression & A-40\%, B-60\%, C-44\% \\
Moderate depression & A-60\%, B-40\%, C-56\% \\
After treatment & Group with $\%$ \\
Normal & A- $100 \%, \mathrm{~B}-96 \%, \mathrm{C}-100 \%$ \\
Mild depression & A-0 $\%, \mathrm{~B}-4.3 \%, \mathrm{C}-0 \%$ \\
After follow-up & Group with $\%$ \\
Normal & A- $100 \%, \mathrm{~B}-96 \%, \mathrm{C}-100 \%$ \\
Mild depression & A- $0 \%, \mathrm{~B}-4.3 \%, \mathrm{C}-0 \%$ \\
\hline
\end{tabular}


Table 3: Data related to the total score

\begin{tabular}{|c|c|c|c|c|c|c|c|c|c|}
\hline \multirow[t]{2}{*}{ Ham-D } & \multicolumn{2}{|c|}{ Group A } & \multicolumn{2}{|c|}{ Group B } & \multicolumn{2}{|c|}{ Group C } & \multicolumn{2}{|l|}{ Total } & \multirow[t]{2}{*}{$\mathbf{p}$} \\
\hline & Mean & SD & Mean & SD & Mean & SD & Mean & SD & \\
\hline BT $(n=25)$ & 14.12 & 2.93 & 12.96 & 3.17 & 14.36 & 2.64 & 13.81 & 2.95 & 0.201 \\
\hline AT $(n=23)$ & 2.61 & 2.08 & 2.17 & 2.19 & 1.17 & 1.34 & 1.99 & 1.97 & 0.039 \\
\hline $\mathrm{AF}(\mathrm{n}=23)$ & 5.52 & 2.83 & 4.13 & 3.96 & 2.87 & 2.42 & 4.17 & 3.28 & 0.021 \\
\hline
\end{tabular}

Table 4: Repeated measure ANOVA

\begin{tabular}{llllll}
\hline Source & $\begin{array}{l}\text { Type III sum } \\
\text { of squares }\end{array}$ & df & $\begin{array}{l}\text { Mean } \\
\text { Square }\end{array}$ & F & p \\
\hline Observations & 5491.855 & 2 & 2745.928 & 862.173 & $<0.001$ \\
$\begin{array}{l}\text { Observations } \\
\text { versus category }\end{array}$ & 87.072 & 4 & 21.768 & 6.835 & $<0.001$ \\
Error & 420.406 & 132 & 3.185 & & \\
\hline
\end{tabular}

After treatment, the average HAM-D score among the control group, first study group, and second study group was $2.61 \pm 2.08,2.17 \pm 2.19$, and $1.17 \pm 1.34$, respectively. There was a significant difference in HAM-D score after treatment among the groups. The second study group experienced a comparatively greater reduction in HAM-D score after treatment than other groups $(\mathrm{p}<0.05)$. A similar trend was maintained after follow-up score. The second study group had a comparatively lesser HAM-D score after follow-up than other groups.

\section{Paired t-test of ham d score in three groups}

The observed successive difference (BT-AT), (AT-AF), and (BT-AF) was statistically highly significant $(\mathrm{p}<0.001)$ in the control group, first study group, and second study group (Table 5).

\section{DISCUSSION}

Mental health is an essential factor in attaining sound health. The aging population is both a medical and sociological problem. The current explosion of non-communicable diseases such as cardiovascular diseases, cancer, and depression in the ever-increasing number of older persons globally, will result in enormous human and social costs unless preventive action is taken.

Withania somnifera reduces stress by delaying the release of cortisol by the adrenals and prevents the negative effect of long-term cortisol production on the body. Ashwagandha is one of the best adaptogenic herbs used in the Ayurvedic system of medicine. Aswagandha was found effective in depression in a clinical trial conducted by Nath et al. [15]. The rhizome-drug Vacha is sedative, tonic, and tranquilizer in action. It is used for brain rejuvenation, cerebral circulation promoter, detoxifies subtle channels, insanity, mental sharpness, memory loss, and insomnia. Both the drugs are Matahari and kaphahara. Apart from this, the formulations also possess the qualities to improve overall health and rejuvenate the body [16].

The yogic treatment of depression focuses on the improvement of mental health to cope up the stressful situations in old age. Postural exercises bring both physical and mental well-being. Studies show that asanas produced a reduction of acetylcholine, an increase of catecholamine levels, decrease of cholesterol, and an enhancement of endocrine functions [17]. Studies show that pranayama brings a reduction in biochemical parameters such as serum cholinesterases, plasma catecholamines, serum lipids, serum cholesterol, and blood sugar [17]. Deep relaxation techniques along with yoga Nidra cause efficient relaxation of the mind and gives freshness to the entire psychosomatic apparatus to restart its work with greater vigor and strength. In the practice of yoga nidra, the inherent tendency to become tense is rooted out and the individual starts viewing the situation as less demanding. A RCT-designed study by Rani et al. (2011) observed the impact of yoga nidra on psychological general well-being in depression
Table 5: Paired t-test of HAM-D score in three groups

\begin{tabular}{lllllll}
\hline \multirow{2}{*}{$\begin{array}{l}\text { Paired } \\
\text { comparison }\end{array}$} & \multicolumn{2}{c}{ Paired difference } & t & p \\
\cline { 3 - 4 } & & Mean & SD & & \\
\hline \multirow{2}{*}{ Group A } & BT versus AT & 11.48 & 2.68 & & 20.56 & $<0.001$ \\
& AT versus AF & -2.91 & 2.54 & & -5.50 & $<0.001$ \\
& BT versus AF & 8.57 & 2.84 & & 14.46 & $<0.001$ \\
Group B & BT versus AT & 10.65 & 2.01 & & 25.37 & $<0.001$ \\
& AT versus AF & -1.96 & 2.51 & & -3.73 & $<0.001$ \\
& BT versus AF & 8.70 & 2.14 & & 19.48 & $<0.001$ \\
Group C & BT versus AT & 13.44 & 2.57 & & 25.04 & $<0.001$ \\
& AT versus AF & -1.70 & 1.94 & & -4.19 & $<0.001$ \\
& BT versus AF & 11.74 & 3.21 & & 17.55 & $<0.001$ \\
\hline
\end{tabular}

among patients with menstrual disorders using HAM-D. In the study, it was concluded that the patients with mild to moderate depression and anxiety symptoms improve significantly with yoga nidra as an intervention [18].

Health retirement study found an age-related increase in depressive symptoms in adults 65 years of age and older [19]. The results showed that $10 \%$ of men aged $65-69$ were depressed compared to $15 \%$ women. In the study, $40 \%$ of men aged 65-69 were depressed compared to $60 \%$ women. Both illiterate and literate population was a prone depression in old age. More percentage of depression is present among the lower level of the education group. Studies conducted by Kennedy Gary et al. and Ramachandran et al. also reported a significantly higher prevalence of depression in the geriatric population belonging to the low socioeconomic status group [19]. A majority of $55 \%$ of the total study population were from rural areas and $45 \%$ from urban areas. A study by Thilak et al. on prevalence and factors associated with depression among the elderly in rural areas of North Kerala showed a prevalence of geriatric depression to be $72.4 \%$ which agrees with the findings of the study [20]. Considering the total population, $61 \%$ were married, $15 \%$ were separated, and $24 \%$ were widows/widower. Studies conducted by Kennedy Gary et al. and Ramachandran et al. had documented a significantly high prevalence of depression among the singles who were either unmarried or widowed, which is not agreeing with the study [21]. Out of the 75 patients, $47 \%$ of patients belonged to the lower socioeconomic class category, $40 \%$ to the middle-class category, and $13 \%$ to the high-class category. One of the main reasons for depression in the study was financial crisis after daughter's marriage, loss of property, and job insecurity in siblings among the lower class and middle-class family. Epidemiological studies reveal that low socio-economic status is generally associated with high psychiatric morbidity, disability, and poor access to healthcare. Ramachandran et al. found that low socio-economic status is one of the factors for geriatric depression [21]. Out of the total study population, $31 \%$ were housewives, $28 \%$ were doing fieldwork, and $41 \%$ were Pensioners. The data show that majority of the population was leading a retirement life. Retirement is also having relation to depression and retirement has been mentioned by Oliffe et al. (2013) [22]. Retirement life reflects on the failed aspirations for wealth and achievement. Depression, after retirement, is seen particularly among men. About $37.3 \%$ of the total population presented a family history of depression. Out of the total study population, $41 \%$ had past psychiatric illness. History of past psychiatric illness is a major factor in inducing depression in old age. Out of the total study population, $97 \%$ had past stressful life events. 
Family breaks up and that was mainly in the female population. Due to family break up most of the population was living lonely in separate houses or old age homes. Out of the total study population, $57 \%$ had a history of alcoholism in the family. Nurnberger et al. in the results of COGA (Collaborative study on the Genetics of Alcoholism). Studies determined the prevalence of major depression and depressive syndrome in the families of the alcoholic probands [23]. Considering the whole study population, $67 \%$ of the patients had no exercise in their regimen and 33\% had regular exercise. This was one of the major findings of the study. Harvey et al. (2010) found an inverse relationship between the amount of leisure-time physical activity and diagnosis-level symptoms of depression. Exercise can be taken as a universal indicator for the prevention of mental illness in old age particularly associated with vascular diseases as this helps in neurogenesis in degenerative age [24].

The diet has a protective effect against the incidence or recurrence of depression as well. Sanchez-Villegas et al. observed that the incidence of depressive disorders was reduced by $25-50 \%$ with the replaced diet [21]. From the study, a majority of $88 \%$ showed mixed dietary habits. Most of the population in all classes of the family had poor knowledge about the diet to be followed in this age group. In the total population, the majority had osteoarthritis followed by diabetes, hypertension, dyslipidemia, and thyroid dysfunctions. Gary et al. and Barua et al. had observed a high prevalence of depression in individuals of geriatric population, who were suffering from four or more comorbid chronic conditions that included diabetes, arthritis, and hypertension bronchial asthma [25].

\section{CONCLUSION}

There was a change in levels of depression from moderate to mild and mild to normal in the study. Reductions levels of depression were seen in three groups after treatment. Results were more significant in the yoga and drug group after treatment and after follow-up.

A combination of Yoga and Ayurveda showed more significant change after treatment and after follow-up. Hence, it can be concluded that a holistic approach can bring a better and static result than either applying the treatment modalities alone.

\section{ACKNOWLEDGMENT}

Dr. Najuma PB Ex-Professor and HOD Department of Swasthavritta, Govt. Ayurveda College, Thiruvananthapuram. Dr. Raj Mohan, Associate Professor, Department of Rasashasthra and Bhaishajyakalpana, Govt. Ayurveda College, Thiruvananthapuram. Dr. Vinuraj Associate Professor, Department of Swasthavritta, Govt. Ayurveda College, Kannur.

\section{AUTHORS CONTRIBUTION}

SM - Concept, data collection, and manuscript preparation. VKS - Design, manuscript editing, and proofreading. JD - Concept, data analysis, manuscript editing, and proofreading.

\section{CONFLICTS OF INTEREST}

No conflicts of interest exist

\section{AUTHOR FUNDING}

This study does not have any funding

\section{REFERENCES}

1. Available from: https://www.emro.who.int $>$ health topics $>$ depression [Last accessed on 2018 Jun 11].

2. Facelift for Old Age Homes; 2019. Available from: https://www. thehindu.com. [Last accessed on 2019 Mar 22].

3. Misra SP. Introduction. In: Yoga and Ayurveda. $3^{\text {rd }}$ ed. New Delhi: Chaukamba Publications; 2004. p. 110-002.

4. Sharma RK, Dash VD. Charaka Samhita Sutrasthana. Ch. 1. Varanasi: Chowkamba Publishers; 2006. p. 19.

5. A Study on Unmada with Special Reference to Manodhukajonmada and the Efficacy of Ashwagandha and Vachacurna in its Management" by Aswin Chandra under the supervision of guide Prof. Dr. SurendranMD, Ph.D. Manovijnana. Kottakkal: VPSV Ayurveda College; 2013.

6. Parameswaran Nair PK. Shudhikrama Sangraha. $1^{\text {st }}$ ed. Thruvananthapuram: Kerala Books; 2005. p. 125.

7. Dilip Kumar KV. Clinical Yoga and Ayurveda. Varanasi: Chowkamba Publishers; 2015. p. 181-98.

8. Bakhru HK. Naturopathy for Longevity. Ch. 7. Mumbai: Jaico Publishers; 2007. p. 72.

9. Dilip Kumar KV. Clinical Yoga and Ayurveda. Varanasi: Chowkamba Publishers; 2015. p. 57-8.

10. Dilip Kumar KV. Clinical Yoga and Ayurveda. Varanasi: Chowkamba Publishers; 2015. p. 64.

11. Dilip Kumar KV. Clinical Yoga and Ayurveda. Varanasi: Chowkamba Publishers; 2015. p. 64-5.

12. Saraswati SS, Muktibhodana S. Hatha Yoga Pradipika. Ch. 2. Munger, Bihar: Yoga Publication Trust; 2016. p. 239.

13. Kumar K. A Handbook of Yoga Nidra. Ramesh Nagar. Ch. 18. New Delhi: D. K. Print World Publishers; 2013. p. 1-55.

14. WINPEPI (PEPI-for-Windows)-Briton Health; 2018. Available from: https://www.brixtonhealth.com [Last accessed on 2018 May 12].

15. Sabins VD. Chemistry and Pharmacology of Ayurvedic Medicinal Plants. $1^{\text {st }}$ ed., Vol. 12. Varanasi: Choukamba Publishers; 2008. p. 387-90.

16. Sastry JL. Dravyaguna Vijnanavol. $2^{\text {nd }}$ ed., Vol. 2, Ch. 82. Varanasi: Chaukamba Publishers; 2005. p. 548-50, 221001.

17. Udupa KN. Stress and its Management by Yoga. $2^{\text {nd }}$ ed., Ch. 10. New Delhi: Motilal Banarsidass Publishers; 1985. p. 110-007. p110, 153

18. Rani K, Tiwari S, Singh U, Agrawal G, Ghildiyal A, Srivastava N. Impact of Yoga Nidra on psychological general wellbeing in patients with menstrual irregularities: A randomized controlled trial. Int J Yoga 2011;4:20-5

19. Federal Interagency Forum on Aging-Related Statistics, Health Retirement Study; 2012. Available from: https://www.agingstats. gov

20. Barua A, Ghosh MK, Kar N, Basilio MA. Socio-demographic factors of geriatric depression. Indian J Psychol Med 2010;32:87-92.

21. Thilak SA, Sarada AK. International Journal of Community Medicine Available from: https://www.ijcmph.com.>article>view [Last accessed on 2019 Apr 20].

22. Oliffe JL, Rasmussen B, Bottorff JL, Kelly MT, Galdas PM, Phinney A, et al. Masculinities, work, and retirement among older men who experience depression. Qual Health Res 2013;23:1626-37.

23. Is there a Genetic relationship between Alcoholism and Depression; 2019. Available from: https://www.pubs.niaaa.nih.gov>arh26-3 [Last accessed on 2019 Apr 14].

24. Harvey SB, Hotopf M, Overland S, Mykletun A. Physical activity and common mental disorders. Br J Psychiatry 2010;197:357-64.

25. Sánchez-Villegas A, Delgado-Rodríguez M, Alonso A, Schlatter J, Lahortiga F, Serra Majem L, et al. Association of the Mediterranean dietary pattern with the incidence of depression: The Seguimiento Universidad de Navarra/University of Navarra follow-up (SUN) cohort. Arch Gen Psychiatry 2009;66:1090-8. 